\title{
Vitamin B Deficiency
}

National Cancer Institute

\section{Source}

National Cancer Institute. Vitamin B Deficiency. NCI Thesaurus. Code C35129.

Abnormally low concentrations of vitamin B in the blood. 